\title{
Use of Memokath, a second generation urethral stent for relief of urinary retention in male spinal cord injured patients
}

\author{
B M Soni MB MS, ${ }^{1} \mathrm{~S}$ Vaidyanatham MS MCh PhD ${ }^{2} \mathrm{~K}$ R Krishnan MB FRCS ${ }^{3}$ \\ ${ }^{1}$ Associate Specialist, ${ }^{2}$ Registrar, ${ }^{3}$ Director and Consultant in Spinal Injuries, Mersey \\ Regional Spinal Injuries Centre, Town Lane, Kew, Southport, Merseyside PR8 6PN, \\ England.
}

\begin{abstract}
Memokath (Engineers \& Doctors A/S, Hornbaek, Denmark) a second generation urethral stent composed of titanium nickel alloy with shape memory effect was deployed in 10 male spinal cord injured patients with urinary retention. The stent was inserted under sterile conditions via a delivery catheter under fluoroscopic control in seven and with the aid of a flexible cystoscope in three. The proximal end of the stent was positioned at the bladder neck and $50 \mathrm{ml}$ of normal saline at $45^{\circ} \mathrm{C}$ was flushed through the stent which resulted in expansion of the distal most four coils of the stent in the proximal bulbar urethra; thus the internal sphincter (bladder neck) and external sphincter zone were kept open by the stent. Urethral stenting helped to achieve complete vesical emptying in all 10 patients. The complications included transient autonomic dysreflexia in two, transient urinary retention due to blood clot in one, and acute urinary tract infection in one patient. With a follow up of 3-7 months, all 10 patients have been aysmptomatic, with residual urine of less than $50 \mathrm{ml}$. There has been no migration or blocking of the stent. However, these stents require replacement at 12-18 months, but it is a short procedure as the Memokath, when cooled with saline at $4{ }^{\circ} \mathrm{C}$, becomes supersoft, enabling its easy and nontraumatic removal. As these stents produce no permanent effect upon the lower urinary tract and their removal is quick, safe and atraumatic, we prefer the second generation nickel titanium alloy stent to transurethral resection of bladder neck, external urethral sphincterotomy or permanent indwelling epithelialising stent, particularly in young spinal cord injured patients who wish to retain their fertility potential.
\end{abstract}

Keywords: urethra; stent; spinal cord injury; tetraplegia.

\section{Introduction}

The concept of stenting the urethral sphincter in spinal cord injured patients, although it may appear to be a novel idea, is certainly not unique to medicine. As early as 1969 , stents were being investigated in the peripheral arterial system as a means of preventing recurrent stenosis after dilation by balloon angioplasty. ${ }^{1}$ Since then, numerous reports have demonstrated the effectiveness of stents in the renal, iliac, femoral, popliteal and coronary arterial systems. Stents also have been used in the gastrointestinal tract to maintain patency of stenotic ducts in the biliary tree. In the lower urinary tract, the initial experience with a permanently indwelling endoprosthesis has been in the bulbar urethra. In 1988, Milroy et $a l^{2}$ reported their preliminary results with eight patients in whom a permanent epithelialising stent was used to treat difficult, recurrent bulbar urethral stricture. With regard to the management of detrusor external sphincter dyssynergia, in 1990 Shaw et $a l^{3}$ described nine patients with complete quadriplegia and detrusor external sphincter dyssynergia who were managed with the UroLume (AMS-Europe, Staines, UK) endoprosthesis instead of an external sphincterotomy. With the follow up ranging from 12 weeks to 12 months, eight patients $(89 \%)$ had marked improvement in bladder 
emptying and the mean post-void residual urine decreased from $260 \mathrm{ml}$ before stent insertion to $92 \mathrm{ml}$.

Chancellor et al in $1993^{4}$ reported the results of a multicentre trial in North America with the UroLume wallstent as an alternative treatment for detrusor external sphincter dyssynergia. For the 119 patients in this investigation, the mean intravesical voiding pressure decreased from $77.7+$ $26.2 \mathrm{~cm}$ water before the endoprosthesis was placed to $26.1+13.4 \mathrm{~cm}$ water at 12 months $(p<0.01)$. During the same period, the post-void residual urine volume decreased from $189+129 \mathrm{ml}$ before insertion to $112+129 \mathrm{ml}(p<0.01)$. Stent migration occurred in five patients $(4.2 \%)$, necessitating removal of the endoprosthesis. However, no other untoward effects were noted. Memokath is a second generation stent composed of titanium nickel alloy with shape memory effect. The spiral can be inserted under sterile conditions via a delivery catheter. When flushed with hot water $\left(45^{\circ} \mathrm{C}\right.$ or above $)$ the distal most section of the spiral expands and maintains the spiral in the proximal bulbar urethra. When cooled with cold water $\left(10^{\circ} \mathrm{C}\right.$ or below), the spiral becomes supersoft, making removal easy. We herein describe our preliminary experience with the use of Memokath in spinal cord injured patients for relief of bladder outlet obstruction.

\section{Patients and methods}

Male spinal cord injured patients with urinary retention due to detrusor-sphincter dyssynergia were the subjects of this study. The exclusion criteria were as follows. (1) $\mathrm{Pa}$ tients who were attending the fertility clinic and were undergoing electroejaculation or who were scheduled for electroejaculation in the near future. (2) Patients with symptomatic urinary tract infection. (3) Patients who were living far away from the centre and who did not have transport of their own. (This exclusion criterion was chosen because of our anxiety that, should there be any problem due to blocking of the stent or migration of the stent, these patients after stent deployment should be able to reach this centre within 2 hours for management of stent related problems.) (4) Presence of a vesical calculus. This was not an absolute contraindication and one patient with coexisting vesical calculus underwent electrohydraulic lithotripsy of vesical calculus followed by stent deployment 5 months later.

The merits and demerits of urethral stenting vis à vis other options that are currently available for treatment of detrusor-sphincter dyssynergia, e.g. division of external urethral sphincter, were discussed with the patient and the procedure of stenting was explained to him. If he agreed to undergo this procedure, he was scheduled for urethral stenting. Intravenous antibiotic (gentamicin $80 \mathrm{mg}$ ) was administered half an hour prior to the procedure. Temazepam $20 \mathrm{mg}$ was given by mouth 1 hour prior to the procedure. The bladder was filled with $100 \mathrm{ml}$ of urographic contrast through the Rüsch (Rüsch UK Ltd, High Wycombe, UK) 14 Fr ruler catheter with which subsequently the distance between the bladder neck and verumontanum was measured. (A stent $10 \mathrm{~mm}$ longer than the measured distance was chosen for deployment.) Contrast in the bladder also helped to delineate the bladder neck region for positioning the stent. Care should be taken to avoid distension of the bladder as it will precipitate an episode of autonomic dysreflexia. $10 \mathrm{mg}$ of phentolamine was given intravenously and the stent-deploying catheter was inserted under fluoroscopic control. The proximal end of the stent was positioned in the bladder neck region. When the stent positioning was satisfactory, $50 \mathrm{ml}$ normal saline at $45^{\circ} \mathrm{C}$ was injected through the main channel of the insertion catheter which resulted in expansion of the distal coils of the stent. The stent-retaining balloon situated beyond the proximal end of the stent was deflated and the insertion catheter was removed leaving the stent in place. Stenting was performed under fluoroscopic control in seven and in three others the stent was placed under vision with the aid of a flexible cystoscope. With the latter method of stent insertion, the distance from the bladder neck to the external sphincter zone was initially measured and a stent of appropriate length was chosen. The proximal end of the stent was positioned at the bladder neck and 
then $50 \mathrm{ml}$ of the normal saline at $45^{\circ} \mathrm{C}$ was injected through the side port which resulted in expansion of the distal coils of the stent. Thereafter, the cystoscope was withdrawn and it could be verified that the stent traversed the sphincter zone. The distal end of the stent should be in the proximal bulbar urethra.

The patient was observed for 2-3 hours for (1) urethral bleeding; (2) febrile reaction; (3) autonomic dysreflexia; and (4) retention of urine. When there was no complication, the patient was allowed to go home and was advised to take oral antibiotics (usually ciprofloxacin $500 \mathrm{mg}$ twice a day for 5 days). He was reviewed after a week and then after a month, on which occasions a urine sample was taken for culture and abdominal ultrasound scan of urinary bladder was performed for measurement of residual urine. Transrectal ultrasound was performed to check the position of the stent, i.e. relationship of proximal end of the stent to the bladder neck.

\section{Results}

The clinical profile of the 10 patients who underwent urethral stenting is given in Table I. Satisfactory deployment of the stent was achieved in all 10 patients. All the patients could void urine immediately after stent placement (Fig 1). No patient developed profuse urethral bleeding or haematuria. Patients 4 and 5 developed features of autonomic dysreflexia immediately after stent placement. Ultrasound scan of the bladder revealed less than $50 \mathrm{ml}$ urine, thus ruling out bladder distension as the aetiological agent for the dysreflexic episode. Both the patients had only a mild degree of haematuria. It was presumed that the dysreflexic episode was due to the foreign body in the urethra. They were prescribed nifedipine $10 \mathrm{mg}$ whenever the systolic blood pressure rose to more than $160 \mathrm{~mm} \mathrm{Hg}$. Within 48 hours, the autonomic dysreflexic episodes subsided and have not recurred so far.

A tetraplegic (patient 7) underwent an uneventful stenting procedure in the afternoon and was discharged home in the evening. However, he developed retention of urine 8 hours later and was admitted in the hospital. A 12 Fr silicone Foley catheter could be passed easily through the stent into the bladder and $400 \mathrm{ml}$ urine was drained along with a few blood clots. The catheter was removed 24 hours later and he has been voiding well and asymptomatic since then. It is presumed that the blood clots blocked the stent leading to urinary retention.

One patient (3) was admitted 2 weeks later with acute urinary tract infection. He was prescribed cefotaxime $1 \mathrm{~g}$ intravenously, 8 hourly for 5 days. Abdominal and transrectal ultrasound scans revealed residual urine of less than $50 \mathrm{ml}$ and proper positioning of the stent with no evidence of stent migration or encrustation over the stent. He has remained well since then. During follow up, no other patient developed symptomatic urinary tract infection. Post-void residual urine has been less than $50 \mathrm{ml}$. There has been no stent migration as revealed by transrectal ultrasonography.

\section{Discussion}

McInerney et $a l^{5}$ stated that the urethral stent when positioned over the external urethral sphincter zone holds the sphincter mechanism so wide open that global detrusor hypertrophy results in the subsequent bladder neck obstruction. Persistent residual urine after transurethral external sphincterotomy has been attributed to bladder neck (internal sphincter) dyssynergia. ${ }^{6}$ Steers $^{6}$ argued that one limitation of stenting the external urethral sphincter alone is the failure to correct obstruction at the internal sphincter or the creation of proximal obstruction. In many of our patients, attempted voiding cystourethrogram showed a closed bladder neck. Hence we preferred to stent both the internal sphincter and the external urethral sphincter. Permanently opening the bladder neck through a self-expanding prosthesis has been recommended as a useful adjunct in the treatment of sphincterotomy patients who have failed the initial procedure. ${ }^{7}$

Stenting of the proximal urethra right from the bladder neck to and beyond the external sphincter helped to achieve complete vesical emptying and to get rid of the 
Table I Clinical profile of patients who underwent Memokath urethral stenting

\begin{tabular}{|c|c|c|c|c|c|c|c|c|}
\hline Patient & $\begin{array}{l}\text { Date of } \\
\text { birth }\end{array}$ & $\begin{array}{l}\text { Date of } \\
\text { injury }\end{array}$ & Diagnosis & $\begin{array}{l}\text { Past urological } \\
\text { operation for urinary } \\
\text { bladder emptying }\end{array}$ & $\begin{array}{l}\text { Current bladder } \\
\text { management }\end{array}$ & $\begin{array}{l}\text { Date urethral } \\
\text { stent } \\
\text { inserted }\end{array}$ & $\begin{array}{l}\text { Size of } \\
\text { stent }\end{array}$ & Method of insertion \\
\hline 1 & 19.04 .56 & 18.01 .76 & $\begin{array}{c}\text { C5 } \\
\text { tetraplegia }\end{array}$ & TURBN (24.1.78) & $\begin{array}{l}\text { Intermittent } \\
\text { catheterisation by } \\
\text { his mother }\end{array}$ & 10.11 .93 & $70 \mathrm{~mm}$ & $\begin{array}{l}\text { Under flouroscopic } \\
\text { control }\end{array}$ \\
\hline 2 & 19.10 .48 & $\begin{array}{c}\text { August } 1967 \\
\text { (viral } \\
\text { infection) }\end{array}$ & $\begin{array}{c}\text { D6 } \\
\text { paraplegia }\end{array}$ & & Self catheterisation & 21.09 .93 & $60 \mathrm{~mm}$ & $\begin{array}{l}\text { Under flouroscopic } \\
\text { control }\end{array}$ \\
\hline 3 & 10.04 .64 & 08.07 .88 & $\begin{array}{c}\text { C5 } \\
\text { tetraplegia }\end{array}$ & & $\begin{array}{l}\text { Indwelling urethral } \\
\text { catheter drainage }\end{array}$ & 01.09 .93 & $60 \mathrm{~mm}$ & $\begin{array}{l}\text { Under flouroscopic } \\
\text { control }\end{array}$ \\
\hline 4 & 09.02 .76 & 12.09 .91 & $\begin{array}{c}\text { C6 } \\
\text { tetraplegia }\end{array}$ & & $\begin{array}{l}\text { Indwelling urethral } \\
\text { catheter drainage }\end{array}$ & 03.08 .93 & $50 \mathrm{~mm}$ & $\begin{array}{l}\text { Under flouroscopic } \\
\text { control }\end{array}$ \\
\hline 5 & 07.03 .47 & 12.04 .84 & $\begin{array}{c}\text { C4 } \\
\text { tetraplegia }\end{array}$ & & $\begin{array}{l}\text { Indwclling urethral } \\
\text { catheter drainage }\end{array}$ & 27.07 .93 & $60 \mathrm{~mm}$ & $\begin{array}{l}\text { Under direct vision } \\
\text { with flexible } \\
\text { cystoscope }\end{array}$ \\
\hline 6 & 23.01 .35 & 23.12 .91 & $\begin{array}{c}\text { C5 } \\
\text { tetraplegia }\end{array}$ & & $\begin{array}{l}\text { Indwelling urethral } \\
\text { catheter drainage }\end{array}$ & 22.09 .93 & $70 \mathrm{~mm}$ & $\begin{array}{l}\text { Under fluoroscopic } \\
\text { control }\end{array}$ \\
\hline 7 & 08.06 .65 & 15.06 .86 & $\begin{array}{l}\text { C5 } \\
\text { tetraplegia }\end{array}$ & & $\begin{array}{l}\text { Indwelling urethral } \\
\text { catheter drainage }\end{array}$ & 17.11 .93 & $60 \mathrm{~mm}$ & $\begin{array}{l}\text { Under fluoroscopic } \\
\text { control }\end{array}$ \\
\hline 8 & 26.04 .38 & 03.04 .90 & $\begin{array}{c}\mathrm{C} 7 \\
\text { tetraplegia }\end{array}$ & & $\begin{array}{l}\text { Indwelling urethral } \\
\text { catheter drainage }\end{array}$ & 26.10 .93 & $70 \mathrm{~mm}$ & $\begin{array}{l}\text { Under direct vision } \\
\text { with flexible } \\
\text { cystoscope }\end{array}$ \\
\hline 9 & 10.03 .56 & 30.04 .73 & $\begin{array}{c}\text { C5 } \\
\text { tetraplegia }\end{array}$ & $\begin{array}{c}\text { Sphincterotomy, } \\
27.11 .73\end{array}$ & $\begin{array}{l}\text { Indwelling urethral } \\
\text { catheter drainage }\end{array}$ & 15.10 .93 & $60 \mathrm{~mm}$ & $\begin{array}{l}\text { Under direct vision } \\
\text { with flexible } \\
\text { cystoscope }\end{array}$ \\
\hline 10 & 25.10 .58 & 09.03 .85 & $\begin{array}{c}\text { C6 } \\
\text { tetraplegia }\end{array}$ & DES, 10.10 .86 & $\begin{array}{l}\text { Indwelling urethral } \\
\text { catheter drainage }\end{array}$ & 19.10 .93 & $70 \mathrm{~mm}$ & $\begin{array}{l}\text { Under fluoroscopic } \\
\text { control }\end{array}$ \\
\hline
\end{tabular}

TURBN $=$ transurethral resection of bladder neck.

DES $=$ division of external urethral sphincter. 


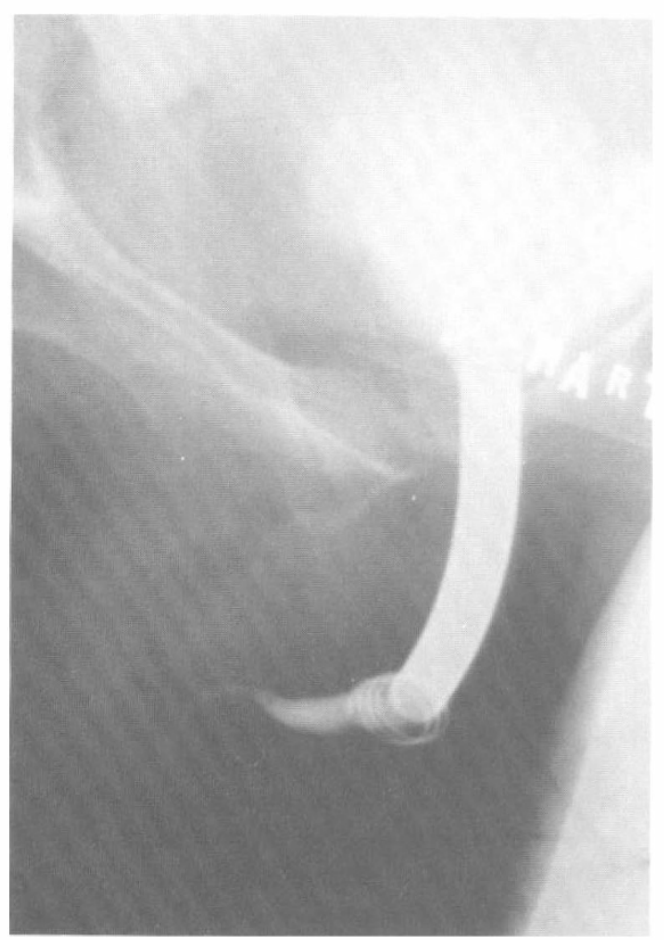

Figure 1 Cystourethrogram after Memokath deployment shows the stent in place with the expanded distal coils

indwelling urethral catheter in these patients. But urethral stenting in spinal cord injured patients poses some peculiar problems which are not encountered in able bodied individuals who undergo prostatic urethral stenting. During transfers (from the bed to the wheelchair etc) there can be minor but significant direct trauma to the perineum which may contribute to proximal migration of the stent. Such an eventuality is never encountered in healthy adult males undergoing prostatic stenting for benign hyperplasia of prostate or urethral stenting for stricture urethra. Similarly, manual evacuation of hard scybali may contribute to 'migration' of the stent in the spinal cord injured patient. This never occurs in the able bodied. The advantage of Memokath is that should migration of the stent occur, it can be easily repositioned with cystoscope and grasping forceps. It is not possible to manipulate the 'instent' as it tends to get deformed. In case one decides to remove the Memokath, the irrigating fluid for cystoscopy can be changed to normal saline at $4{ }^{\circ} \mathrm{C}\left(10^{\circ} \mathrm{C}\right.$ or below $)$ when the spiral becomes supersoft. When the grasping forceps engage the lower coil and it is pulled gently, the Memokath is transformed into a soft long wire and retraction is easily performed. The soft wire is unlikely to damage the mucous membrane of the urethra.

Poulsen et $a l^{8}$ encountered bullous oedema in the urethral mucous membrane in four of the 30 consecutive patients with prostatic outflow obstruction in whom Memokath was inserted for relief of outlet obstruction. These authors concluded that, although titanium nickel shape memory alloy is known to be highly biocompatible, a local reaction to this material in the urethral lining could not be excluded. They suggest that as per the consensus at the International Academy of Shape Memory Material for Medical Use in 1992, the titanium nickel alloy should not be used in patients with nickel allergy.

Chancellor et al $\boldsymbol{M}^{\boldsymbol{9}}$ deployed the prosthesis in such a manner that the proximal location of the stent was halfway on the verumontanum and the distal end of the stent was in the bulbar urethra, at least $5 \mathrm{~mm}$ beyond the end of the external sphincter. Chancellor et $a l^{\text {' }}$ successfully carried out electroejaculation after such a placement of a Urolume endourethral wallstent prosthesis, with recovery of motile sperm evident at semen analysis in a spinal cord injured patient. McInerney et $a l^{5}$ suggested that for patients requiring fertility investigation and treatment, the stent should be placed distal to the verumontanum so that the stent does not obstruct the ejaculatory ducts. We were concerned about the possible effect of electroejaculation upon the urethra after placement of a titanium nickel prosthesis. Hence, as of today, we do not recommend this stent in patients who are likely to undergo electroejaculation for their fertility programme. Alternatively, the Memokath could be removed just prior to electroejaculation and then a new stent can be inserted at the end of electroejaculation under the same anaesthesia.

The current literature on urethral stenting in spinal cord injured patients has been 
Table II Summary of the current literature on urethral stenting in cases of neuropathic bladder: type of stent and technique of stent insertion

\begin{tabular}{|c|c|c|c|c|}
\hline Author \& year & Type of stent & $\begin{array}{l}\text { Total number of } \\
\text { patients }\end{array}$ & $\begin{array}{l}\text { No. of patients who had } \\
\text { prior sphincterotomy }\end{array}$ & Method of placement of stent \\
\hline Niku et al (1993) ${ }^{10}$ & Urolume urethral stent & 10 & 4 & Endoscopically \\
\hline $\begin{array}{l}\text { Saverweir et al } \\
(1993)^{11}\end{array}$ & Wallstent & 51 & $\begin{array}{l}35 \text { had undergone } 2 \\
\text { sphincterotomies; } 16 \text { had } \\
\text { more than 2; } 10 \text { had } \\
\text { undergone } 4\end{array}$ & - \\
\hline $\begin{array}{l}\text { Chancellor et al } \\
(1993)^{9}\end{array}$ & $\begin{array}{l}\text { Urolume endourethral } \\
\text { wall stent }\end{array}$ & $\begin{array}{l}23 \text { were tetraplegics } \\
\text { and } 2 \text { were paraplegics }\end{array}$ & 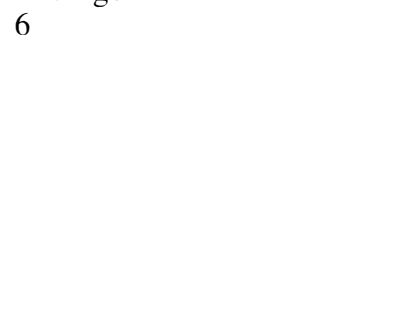 & $\begin{array}{l}\text { Inserted with a } 21 \mathrm{Fr} \text { cystoscopic } \\
\text { insertion tool with a telescope. The } \\
\text { stent was positioned so that the } \\
\text { proximal location of the prosthesis } \\
\text { is half way on the verumontanum. } \\
\text { The distal end of the prosthesis } \\
\text { should be in the bulbar urethra at } \\
\text { least } 5 \mathrm{~mm} \text { beyond the end of the } \\
\text { external sphincter }\end{array}$ \\
\hline Shaw et al $(1990)^{3}$ & $\begin{array}{l}\text { Wallstent (Medinvert } \\
\text { SA, Lausanne, Switzer- } \\
\text { land) }\end{array}$ & 9 & $\mathrm{Nil}$ & $\begin{array}{l}\text { Cystourethroscopy was performed } \\
\text { to ensure that urethral appearances } \\
\text { were normal, to wash out debris } \\
\text { within the bladder and to allow } \\
\text { placement under direct vision of a } \\
\text { suprapubic catheter which was to } \\
\text { be left in place for } 6 \text { weeks. The } \\
\text { stent was inserted under direct } \\
\text { vision. Its proximal end was placed } \\
\text { at the level of verumonatnum and } \\
\text { the distal end in the proximal bul- } \\
\text { bar urethra }\end{array}$ \\
\hline Noll et al $(1992)^{12}$ & Wallstent & $\begin{array}{l}24 \text { spastic bladders } \\
\text { with severe detrusor- } \\
\text { sphincter dyssynergia }\end{array}$ & $\begin{array}{l}17 \text { had undergone failed } \\
\text { sphincterotomies }\end{array}$ & - \\
\hline
\end{tabular}


Table III Résumé of the literature on urethral stenting

\begin{tabular}{ll}
\hline Author \& year & $\begin{array}{l}\text { No. of patients who } \\
\text { had 2 stents }\end{array}$ \\
\hline Niku et al (1993) ${ }^{10}$ & 3 \\
$\begin{array}{l}\text { Saverweir et } \quad \text { al } \\
(1993)^{11}\end{array}$ & - \\
$\begin{array}{l}\text { Chancellor et } \\
(1993)^{9}\end{array}$ & $\begin{array}{l}7 \text { of the 25 patients } \\
\text { (28\%) required place- } \\
\text { ment of } 2 \text { prostheses at } \\
\text { surgery to completely } \\
\text { bridge the external } \\
\text { spincter }\end{array}$
\end{tabular}

Shaw et al $(1990)^{3} \quad$ In 1 patient, 3 stents were overlapped from the bladder to the bulbar urethra. Two patients required additional stents to complete the 'sphincterotomy', 1 at the same sitting and the other 2 weeks later when bladder emptying was found

to be inadequate
Stent migration

Stent removal

1, due to persistent

autonomic dysreflexia

Problems are anticipated in removal of the implants

The two prostheses that migrated distally into the bulbar urethra were removed with cystoscopic guidance without difficulty and were replaced with new prostheses

-

Noll et al (1992) 12
It is anticipated that proximal migration of stents may occur in patients who had undergone bladder neck resection earlier

One prosthesis migrated $5 \mathrm{~mm}$ proximally into the prostatic urethra. In this patient with proximal stent migration a second prosthesis was placed overlapping the first

In 1 patient the stent had retracted $1 \mathrm{~cm}$ into the prostatic fossa. A bladder neck incision to the level of the stent was performed plete bladder emptying has not ocsphincterotomy

Wallstents seem to be satisfactory curred in all cases

The results obtained equal those of a well performed 12 o'clock

Authors' comments on urethra stenting

Urolume urethral stent offers an excellent alternative to sphincterotomy. Its success rate is excellent and morbidity is minimal or patients with detrusor-sphincte dyssynergia after failure of the first sphincterotomy. Possibly it is even an alternative procedure to sphincterotomy

The simplicity of placement and minimal associated morbidity makes the sphincter prosthesis a potentia alternative to external sphincterotomy

One patient retains his suprapubic catheter for drainage because of incomplete bladder emptying. The first 3 patients developed symptoms of postoperative autonomic dysreflexia of uncertain aetiology. Com- 
summarised in Tables II and III. Oesterling, ${ }^{13}$ who recently reported the long term results of the North American clinical trial on the Urolume endoprosthesis as a treatment for recurrent bulbar urethral strictures, stated that a permanently indwelling endoprosthesis may be a valuable alternative to external sphincterotomy for the treatment of detrusor external sphincter dyssynergia. If stents are introduced into an environment that has microorganisms (e.g. urinary tract), bacteria will colonise the surface irreversibly, precluding any form of tissue incorporation. The adaptive mechanisms of bacteria by which they attach permanently to the surface of prostheses are well recognised ${ }^{14}$ and explain the inability of eukaryotic cells to compete effectively for the colonisation of the surfaces. This is probably why stents do not get incorporated in tubular structures lined by mucosal tissue. Despite the apparent coverage of the stent surface by mucosal growth at endoscopy, histologic examination shows proliferation through the metal interstices. ${ }^{15}$ Although some of these polypoid growths coalesce over the metal, the stent is not truly incorporated in the wall thickness because mucosal cells are still present on the abluminal side of the stent. ${ }^{16}$ Recently a bioresorbable urethral stent has been investigated in rabbits by Kemppainen et al. ${ }^{17}$ The bioresorbable urethral stent is made of biodegradable self-reinforced poly-L-lactide to achieve an active initial tissue reaction and better tissue penetration. As the tissue reaction around the bioresorbable stent material is minimal, the chances of stenosis due to exuberant fibrotic proliferation requiring endoscopic treatment which has been reported with the self-expandable urethral stent (wallstent) may be diminished in case of the bioresorbable stent. Thus the controversy remains as to whether we should use a permanent epithelialising endoprosthesis, or a bioresorbable urethral stent or a stent which can be removed easily such as the Memokath in spinal cord injured patients. Recently, the intravascular stents are being coated to diminish the thrombogenic properties. Similarly, coating can be made to the urethral stents to prevent bacterial colonisation and encrustations.
Stent coatings can be classified as biological or prosthetic; the latter can be subdivided into passive coating and active coating. Active coatings include several new materials that can incorporate drugs such as low molecular weight heparin released slowly for sustained local action. Biological coating is represented by seeding of endothelial cells over the stent surface before deployment. Dichek et al ${ }^{18}$ reported successful seeding of endothelial cells genetically engineered by recombinant DNA techniques to produce tissue plasminogen activation over the stents. The search for the ideal urethral stent is continuing and devices made of superior design and material will hopefully be made available soon for spinal cord injured patients. However, more studies with a large number of patients and extended follow up will be necessary to confirm initial findings, determine the durability of the stents and assess late complications in spinal cord injured patients whose chances of survival have much improved because of the global care being provided by specialised spinal injury centres. As of today, the permanent epithelialising endoprosthesis and the second generation temperature-sensitive Memokath stent composed of titanium nickel alloy with shape memory effect are the main contenders for deployment in the spinal cord injured patient. We believe that each stent has its own indications and they are not competitors, but complement each other in providing individualised care. For example, in a 20 year old tetraplegic with detrusor-sphincter dyssynergia, who is not yet married, and for whom preserving his fertility is one of the main considerations, division of the external sphincter is completely ruled out. We prefer to insert a Memokath in this patient so that when he plans his family, the Memokath can be easily removed and he can safely undergo an electroejaculation schedule. However, in a 60 year old tetraplegic patient with sphincterotomy failure, and who has completed his family, a permanently indwelling epithelialising endoprosthesis is a one time procedure and the risks of a possible obstruction of the ejaculatory ducts are of minor concern and can be ignored. In contrast, the Memokath stent will require replacement at least once 
in 12-24 months. It has been stated that the epithelialising stents can be removed transurethrally at any time if necessary; irrespective of the stent design, the overlying epithelium can be resected using a low cutting current, and the stent is then freed from its bed and removed through a protective instrument, such as a resectoscope sheath. Current experience on removal of the epithelialising stents and consequences of such removal on the urethra and the ejaculatory duct orifices is very limited and we would be sceptical in making any assurance to our patients regarding the safety of such a procedure. On the other hand, the Memokath can be safely removed without causing any temporary or permanent damage to the urethra after it is cooled with normal saline at $4{ }^{\circ} \mathrm{C}$.

In conclusion, urethral stenting represents a major therapuetic innovation in the management of the neuropathic bladder. Continued research into the basic biology of tissue-stent interactions and coating of the stents to prevent bacterial colonisation and encrustations, along with improved stent design, will lead to further advances in the care of spinal cord injury patients.

\section{References}

1 Dolter CT (1969) Transluminally placed coilspring endarterial tube grafts: long-term patency in canine popliteal artery. Invest Radiol 4: 329.

2 Milroy EJ, Chapple CR, Cooper JE et al (1988) A new treatment for urethral strictures. Lancet 1: 1424.

3 Shaw PJR, Milroy EJG, Timoney AG et al (1990) Permanent external striated sphincter stents in patients with spinal injuries. Br J Urol 66: 297-302.

4 Chancellor MB, Ackman D, Appell RA et al (1993) Multicentre trial in North America of Urolume urinary sphincter prosthesis. J Urol, Part 2, 149: 358, Abstract 580.

5 McInerney PD, Vanner TF, Harris SAB, Stephenson TP (1991). Permanent urethral stents for detrusor sphincter dyssynergia. Br J Urol 67: 291-294.

6 Steers W. Editorial comment. In: Gillenwater JY, Howards SS, editors. Year Book of Urology 1992. Mosby Year Books, London: 96-97.

7 Santiago JA (1993) Sphincterotomy failure. J Am Paraplegia Soc 16: 164-168.

8 Poulsen AL, Shou J, Ovesen H, Nordling J (1993) Memokath: a second generation intraprostate spirals. $\mathrm{Br}$ J Urol 72: 331-334.

9 Chancellor MB, Krusick S, Erhard MJ et al (1993) Placement of a wire mesh prosthesis in the external sphincter of men with spinal cord injuries. Radiology 187: 551-555.

10 Niku D, Joseph A, Juma S (1993) Urethral stent for detrusor sphincter dyssynergia. J Urol 149: 268 A.

11 Salterwein D, Kutzenberger J, Gross AJ (1993) Wallstents in patients with detrusor sphincter dyssynergia. J Urol Part 2, 149: 268, Abstract 220.

12 Noll F, Hock V, Schreiter F (1992) Wallstent for treatment of bulbar urethral stricture and DSD in spastic bladder. Urologe-A 31: 290-295.

13 Osterling JE (1993) Stenting the male lower urinary tract: a novel idea with much promise. J Urol 150: $1648-1649$.

14 Gristina AG (1987) Biomaterial centered infection: microbial adhesion versus tissue integration. Science 237: $1588-1595$.

15 Alvarado R, Palmaz JC, Garcia OJ et al (1989) Evaluation of polymerwated balloon expandable stents in bile ducts. Radiology 170: $975-978$.

16 Palmaz JC (1993) Intravascular stents: tissue-stent interactions and design considerations. AJR 160: 613-618.

17 Kemppainen E, Talja M, Riihela M et al (1993) A bioresorbable urethral stent. An experiment study. Urol Res 21: 235-238.

18 Dichek DA, Neville RG, Zwiebel JA et al (1989) Seeding of intravascular stents with genetically engineered endothelial cells. Circulation 80: 1347-1353. 